\title{
4
}

\section{Psychosocial Support Needs of Families of Boys with Duchenne Muscular Dystrophy}

\author{
Jean K. Mah1,* and Doug Biggar² \\ ${ }^{1}$ Alberta Children's Hospital, University of Calgary, Calgary, Alberta, \\ ${ }^{2}$ Bloorview Kids Rehab, University of Toronto, Ontario, \\ Canada
}

\section{Introduction}

Duchenne muscular dystrophy (DMD, OMIM \#310200) is the most common form of muscular dystrophy in childhood, with an incidence of approximately 1 per 3,500 live-born males [Emery, 1991]. It is caused by mutations of the DMD gene located on Xp21 which codes for dystrophin, a $427-\mathrm{kDa}$ protein that is expressed at the sarcolemma of skeletal muscle. The dystrophin gene contains 79 exons, which includes an actin-binding domain at the N-terminus, 24 spectrin-like repeat units, a cysteine-rich dystroglycan binding site, and a C-terminal domain [Hoffman et al, 1987; Koenig et al, 1988]. The large size of the dystrophin gene results in a complex mutational spectrum $(>4,700$ different mutations) as well as a high spontaneous mutation rate [Aartsma-Rus et al, 2006]. Large deletions account for approximately $65 \%$ of DMD mutations while duplications occur in up to $10 \%$ of males with DMD. The remaining $25 \%$ include small deletions, insertions, point mutations, or splicing mutations. About two-thirds of DMD cases are inherited from mothers carrying the mutations, with the remaining one-third occurring as spontaneous mutations [Laing, 1993]. According to Monaco et al, DMD-causing mutations are typically associated with an out-offrame mutation leading to a loss of functional gene product, whereas in-frame mutations that allow synthesis of an internally truncated but functional protein result in a milder Becker muscular dystrophy (BMD) phenotype [Monaco et al, 1988].

Dystrophin is an integral component of the dystrophin glycoprotein complex. It stabilizes the muscle membrane by bridging the basal lamina of the extracelluar matrix to the inner cytoskeleton of the contractile elements [Rybakova et al, 2000]. It also serve as a transmembrane signalling complex which is essential for cell survival [Chen et al, 2000]. Loss of dystrophin results in excessive membrane fragility, unregulated influx of calcium ions into the sarcoplasm, mitochondrial dysfunction, and increased oxidative stress, leading to progressive muscle degeneration, fibrosis, and fatty replacement [Wallace \& McNally, 2009]. Early presenting features in DMD include developmental delay, proximal muscle weakness as evident by Gowers' sign and waddling gait, as well as varying degree of

${ }^{*}$ Corresponding Author 
cognitive impairment and learning disability [Fitzpatrick et al, 1986; Leibowitz \& Dubowitz, 1981]. Serum creatine kinase is usually markedly elevated due to on-going muscle damage and regenerative failure. Progressive muscle weakness leads to loss of independent ambulation by early teens, scoliosis, quadriplegia, respiratory insufficiency, cardiomyopathy, and death around the third decade of life.

Detection of $D M D$ mutations include multiplex polymerase chain reaction (PCR) that examines the most commonly deleted regions of the gene, or other molecular genetic assays that interrogate all 79 exons, such as multiplex ligation-dependent probe amplification (MLPA) and comparative genomic hybridization (CGH) microarray. If the presence of a disease-causing deletion or duplication is not identified by a state-of-the-art DNA diagnostic technique, complete gene sequencing is needed to define the precise mutational event [Baskin et al, 2009; Takeshima et al, 2010]. A muscle biopsy can also be obtained for confirmation of dystrophin deficiency by immunostaining plus extraction of cDNA and RNA for further genetic testing [Mah et al, 2011].

Recent scientific advances have led to potentially new disease modifying treatments for many neuromuscular diseases including DMD [Wagner, 2008; Fairclough et al, 2011]. The main therapeutic strategies include: a) muscle membrane stabilization and up-regulation of compensatory cytoskeleton proteins such as biglycan and utrophin [Amenta et al, 2011; Tinsley et al, 2011]; b) enhancement of muscle regeneration via up-regulation of insulin growth factor (IGF-1) and modulation of members of transforming growth factor-beta such as myostatin [Schertzer et al, 2008; Morine et al, 2010]; c) reduction of the inflammatory cascade by selective nuclear factor-kappa B (NF-kB) inhibition [Tang et al, 2010]; and d) gene therapy including the use of adeno-associated virus microdystrophin [Trollet et al, 2009], nonsense suppression therapy [Welch et al, 2007; Malik et al, 2010], and exon-skipping to restore partial dystrophin protein production [Muntoni et al, 2005; van Deutekom et al, 2007]. Effective treatment of DMD will likely require multiple interventions targeting different disease processes, and updated information about DMD clinical trials is available at http://www.clinicaltrials.gov. The success of new and emerging therapeutic strategies depends on early diagnosis and precise mutational analysis for boys with DMD, the creation of a national or global disease-specific patient registries, plus on-going advocacy and interdisciplinary collaboration.

\section{Current management strategies}

Until there is a definitive cure for DMD, current treatment strategies focus on promoting well-balanced diet and physical activity as tolerated, delaying the onset of complications via pharmaceutical treatments, and optimizing health outcomes through appropriate medical and psychosocial support. Therapeutic interventions include the use of corticosteroids (such as prednisone or deflazacort) for skeletal muscle weakness and afterload reduction (such as angiotensin converting enzyme inhibitor or beta-blocker) for cardiomyopathy. Corticosteroid therapy offers benefit to DMD boys by improving muscle strength and function [Mendell et al, 1989; Griggs et al, 1991], prolonging independent ambulation [Biggar et al, 2001; Schara et al, 2001], plus slowing the progression of cardiomyopathy [Markham et al, 2008] and scoliosis [Kinali et al, 2007]. As well, the introduction of noninvasive positive pressure ventilation has prolonged the survival of individuals with DMD [Bach \& Martinez, 2011]. 
A number of recent publications have provided comprehensive reviews on the diagnosis and multidisciplinary management of DMD, including the use of prednisone or deflazacort to preserve muscle strength [Bushby et al, 2004; Moxley et al, 2005], optimizing growth and development, surveillance for spinal deformities [Muntoni et al, 2006], managing respiratory complications [Finder et al, 2004; Birnkrant et al, 2010], and treating cardiomyopathy [American Academy of Pediatrics, 2005; Baxter, 2006]. As well, bone health, nutrition, learning disability, behaviour problems, access to wheelchair and other adaptive technology should be included as part of the comprehensive treatment plan [Bushby et al, 2010a; Bushby et al, 2010b]. As standard of care guidelines typically focus on medical management and there are no systematic strategies to meet the psychosocial needs of boys with DMD and their families, the remaining of this paper will present some of our results on pediatric HRQOL, parental experience, and family-centered care approach to DMD that may help to identify the needs and incorporate psychosocial support strategies into clinical practice. We propose the use of a modified Family Needs Survey for DMD (DMD-FNS) to help clinicians to address needs and tailor services for each family across the different stages of the disease.

\section{DMD and health-related quality of life}

Chronic neurological disorders such as DMD have a significant impact on pediatric health-related quality of life (HRQOL) and functional ability. Both medical services and community-based programs are often required to address their physical, emotional, social, and educational needs. A large prospective study led by Dr. Craig McDonald and his colleagues will provide valuable longitudinal data on the natural history of DMD, associated HRQOL, and health services utilization; this 5-year study includes more than three hundred boys with a confirmed diagnosis of DMD from 20 participating CINRG centers in the United States and other international sites (personal communication). Given the lack of information on the processes of care and health outcomes of children with chronic neurological disabilities in Canada, a brief 3-month cross-sectional pilot survey was performed at the Alberta Children's Hospital, a tertiary pediatric neurosciences center in Calgary, Alberta to explore the use of health services and HRQOL among DMD and other pediatric neurosciences patients. Specifically, parents of 278 children (165 male, mean age $=11 \pm 4.5$ years) were asked to describe their child's functional ability, healthrelated quality of life (HRQOL), and use of health services including access to medical professionals, rehabilitation programs, education, and social support in their communities. The children were followed because of chronic neurological diseases including brain tumour $(n=33)$, traumatic brain injury $(n=23)$, hydrocephalus $(n=46)$, myelomeningocele $(n=29)$, refractory epilepsy $(n=89)$, or neuromuscular disease $(n=58)$, including 14 boys with DMD. As part of the study procedure, the parents completed questionnaires regarding their socio-demographic status, their experience with rehabilitative and supportive services, their child's functional ability using the Functional Independence Measure (FIM ${ }^{\mathrm{TM}} / \mathrm{WeeFIM}^{\circledR}$ ), and their child's HRQOL using the PedsQLTM (version 4.0) generic core.

The FIM and WeeFIM are designed to measure functional abilities and limitations in activities of daily living. The FIM is used for persons seven years of age or older, while the WeeFIM is designed for children between six months to seven years in age. Both versions 
measure independent performance in self-care, sphincter control, transfers, locomotion, communication, and social cognition. Response to each of the items ranges from 1 to 7 , with higher scores indicating more independence. A total score is calculated by combining scores from all eighteen items, and ranges from 18 to 126. The psychometric properties of the FIM have been described in previous studies [Chau et al, 1994; Msall et al, 1994; Ottenbacher et al, 1997].

The PedsQL (version 4.0) generic core scale is a self-report multidimensional instrument designed by Varni et al to measure pediatric HRQOL [Varni et al, 1999]. The raw score for each item is transformed to a 0 to 100 scale, with a higher score indicating better quality of life. It has been validated for use in children [Varni et al, 2001]. The study was approved by the University of Calgary Conjoint Health Research and Ethics Board.

Among the 278 children, close to one-half (49\%) had some limitations in daily activities, as reflected by their mean total FIM score of 90.6 (SD 34.4, max FIM score = 126). Approximately $25 \%$ were severely disabled and totally dependent on caregivers for selfcare, sphincter control, and transfer. Nearly $40 \%$ of patients received regular (weekly to monthly) rehabilitation therapy. The majority of health services were financed by government health care program; $73(27 \%)$ families reported additional out-of-pocket expenses. As anticipated, the use of supportive health services such as physiotherapy or occupational therapy was related to the child's diagnosis, degree of functional ability, and his/her HRQOL (see Table 2). On the other hand, socio-demographic variables such as parental age, marital status, education, employment, and place of residence were not significantly associated with health services utilization, except that parental income was associated with varying degree of funding support from the government. Only a small proportion (32\%) of these families had access to regular respite, and the frequency of respite correlated with the severity of disability. Having a designated care coordinator was consistently associated with increased use of health services (OR 2.3 to 3.4).

Even though many pediatric neurosciences patients experienced significant functional limitations and required rehabilitative services, the majority $(83 \%)$ of parents in this study felt that there was adequate medical, educational and financial support in their communities. However, almost half (49\%) of the families indicated need for more psychosocial support, despite adequate medical, rehabilitative, and educational services. Parents from visible minority groups, those with English as a second language, and those who reported poor mental health were more likely to express need for more social support.

Overall, the physical and psychosocial HRQOL scores for this group of children were lower than published healthy controls; their mean PedsQL physical and psychosocial scores were 63.2 (SD 30.1) and 65.9 (SD 22.4) respectively (maximum PedsQL score $=100$ ). Children with refractory epilepsy had the lowest mean psychosocial scores, while those with DMD and other neuromuscular diseases scored lowest on the physical scale (see Table 1). This suggests that despite their physical limitations, children with neuromuscular diseases enjoyed better HRQOL than those with refractory epilepsy. As seen in a subsequent study, children with DMD and other progressive neuromuscular diseases experienced further decline in their HRQOL, especially when they required the use of assisted mechanical ventilation at home [Mah et al, 2008]. 


\begin{tabular}{lccc}
\hline & Mean & SD & Frequency \\
\hline Physical functioning (/100) & & & \\
- Neuromuscular Disease & 52.49 & 30.59 & 57 \\
- Myelomeningocele & 58.92 & 26.87 & 29 \\
- Hydrocephalus & 68.56 & 31.13 & 45 \\
- Brain Injury & 85.64 & 21.69 & 23 \\
- Brain Tumour & 83.09 & 20.26 & 33 \\
- Refractory Epilepsy & 53.99 & 30.81 & 88 \\
Psychosocial functioning (/100) & & & \\
- Neuromuscular Disease & 68.05 & 21.10 & 58 \\
- Myelomeningocele & 69.61 & 18.33 & 29 \\
- Hydrocephalus & 68.25 & 23.89 & 45 \\
- Brain Injury & 72.32 & 16.63 & 23 \\
- Brain Tumour & 80.96 & 17.90 & 33 \\
- Refractory Epilepsy & 54.10 & 21.36 & 89 \\
\hline
\end{tabular}

Table 1. Comparison of Pediatric Health-Related Quality of Life Scores among children with chronic neurological disorders

\begin{tabular}{llcccc}
\hline Dependent variable & Independent variables & Odds Ratio & Wald's test & p value & 95\% CI \\
\hline 1. Utilization of & Child's age & 0.911 & -2.90 & 0.004 & $0.855-0.970$ \\
Medical & Surgery & 2.672 & 3.29 & 0.001 & $1.488-4.799$ \\
specialists & Psychosocial HRQOL & 0.979 & -3.13 & 0.002 & $0.965-0.992$ \\
& Care coordinator & 3.407 & 4.03 & 0.000 & $1.877-6.184$ \\
2. Utilization of & Diagnosis & & & & \\
Allied Health & Myelomeningocoele & 0.295 & -2.09 & 0.037 & $0.094-0.927$ \\
Professionals & $\quad$ Hydrocephalus & 0.069 & -3.92 & 0.000 & $0.018-0.263$ \\
& $\quad$ Brain injury & 0.025 & -3.13 & 0.002 & $0.002-0.251$ \\
& $\quad$ Brain tumor & 0.261 & -2.06 & 0.039 & $0.073-0.935$ \\
& $\quad$ Epilepsy & 0.207 & -3.13 & 0.002 & $0.077-0.555$ \\
& Child's age & 0.851 & -3.76 & 0.000 & $0.783-0.926$ \\
& FIM score & 0.969 & -5.03 & 0.000 & $0.957-0.981$ \\
& Psychosocial HRQOL & 0.978 & -2.39 & 0.017 & $0.961-0.996$ \\
& Care coordinator & 2.419 & 2.26 & 0.024 & $1.124-5.207$ \\
3. Utilization of & FIM score & 0.975 & -3.64 & 0.000 & $0.961-0.988$ \\
Educational & Psychosocial HRQOL & 0.960 & -3.69 & 0.000 & $0.939-0.980$ \\
Services & Parental education & 2.521 & 2.09 & 0.037 & $1.060-5.998$ \\
& Care coordinator & 3.359 & 2.97 & 0.003 & $1.509-7.477$ \\
4. Access to Social & FIM score & 0.961 & -6.96 & 0.000 & $0.950-0.972$ \\
Support & Care coordinator & 2.294 & 2.62 & 0.009 & $1.232-4.272$ \\
5. Access to & Psychosocial HRQOL & 0.977 & -2.46 & 0.014 & $0.959-0.995$ \\
Funding Support & Family income & 2.375 & 2.37 & 0.018 & $1.160-4.864$ \\
\hline
\end{tabular}

† Health-related quality of life

‡Functional Independence Measure

Table 2. Multiple regression analysis of rehabilitation and supportive services utilization by children with chronic neurological disorders 


\section{Impact of home mechanical ventilation on HRQOL}

The purpose of this study was to explore the impact of the use of life-sustaining assisted technologies such as home mechanical ventilation (HMV) on children and adolescents with NMD. We compared the HRQOL and parental stress among pediatric neuromuscular patients with or without home mechanical ventilation, and again boys with DMD $(n=24)$ were included as part of the study. Parents completed the Parenting Stress Index or the Stress Index for Parents of Adolescents, depending on their child's age. The Parenting Stress Index is a 120-item questionnaire that has been standardized for use with parents of children aged 1 month to 12 years [Abidin, 1993]. Each item is rated on a 5-point Likert-type scale that ranges from 1 (strongly agree) to 5 (strongly disagree). A Total Stress score, a Child Domain score, and a Parent Domain score are calculated from the responses. The 112-item Stress Index for Parents of Adolescents is an upward extension of the Parenting Stress Index for parents of adolescents aged 12 to 18 years [Sheras et al, 1998]. The Stress Index for Parents of Adolescents examines the relationship of parenting stress to adolescent characteristics, parent characteristics, the quality of adolescent-parent interactions, and stressful life circumstances. A Total Stress score, an Adolescent Domain score, a Parent Domain score, an Adolescent-Parent Relationship Domain score and a Life Stress score are calculated from the responses. Support for the content, convergent and discriminant validity of both versions of the Parental Stress Index is available. The PedsQL (version 4.0) generic core was again used to measure the HRQOL of children with neuromuscular disease.

109 families participated; 19 (17\%) of them had a child with neuromuscular disease requiring HMV. Relative to healthy children and other chronically ill children, the pediatric neuromuscular patients in this study displayed poorer physical and psychosocial HRQOL. In addition, children on HMV had significantly lower mean total PedsQL scores than nonventilated children ( 47.9 vs. 61.5 respectively, $p=0.013$ ) (see Table 3 ); the difference was likely the consequence of a more severe disease process in children requiring assisted ventilation. Furthermore, the opportunities that these children have to be involved in social activities outside of home and at school may be limited by the lack of portability of the assisted ventilation devices and/or availability of trained caregivers. However, no significant difference in mean total stress scores was found between parents of pediatric neuromuscular patients with or without HMV. We postulated that these parents had been living with the constant demands of caring for their child with neuromuscular disease requiring home mechanical ventilation and that over time, these caretaking demands had become part of "normal" life and were not identified as creating additional stress.

\begin{tabular}{llcccc}
\hline Mean PedsQL* Scores & $\begin{array}{c}\text { HMV } \\
\text { Status }\end{array}$ & Number & Mean & $\begin{array}{c}\text { Standard } \\
\text { deviation }\end{array}$ & p value \\
\hline Physical & Non-HMV & 92 & 54.85 & 27.53 & 0.001 \\
& HMV user & 14 & 28.82 & 22.38 & \\
Psychosocial & Non-HMV & 87 & 63.22 & 18.89 & 0.028 \\
\multirow{2}{*}{ Total } & HMV user & 13 & 51.06 & 13.87 & \\
& Non-HMV & 91 & 61.54 & 18.91 & 0.013 \\
& HMV user & 13 & 47.93 & 12.01 & \\
\hline
\end{tabular}

* PedsQL refers to Pediatric Quality of Life Inventory; ${ }^{\dagger}$ HMV refers to Home Mechanical Ventilation

Table 3. Comparison of Mean Pediatric Quality of Life Inventory scores between Mechanically Ventilated and Non-Ventilated Pediatric Neuromuscular Subgroups [Mah et al, 2008a].

Reproduced with permission. 


\section{Understanding the parental experience}

In order to further understand parental stress and psychosocial support needs of families caring for children with DMD and other neuromuscular diseases (NMD), a qualitative research study based on phenomenology was used to describe the experience of parents caring for children affected by NMD requiring HMV [Mah et al, 2008]. Data was collected from interviews in parents' homes. The interviews were subsequently modified based on an iterative approach to identify the core of the parents' caregiving experience (see Figure 1).

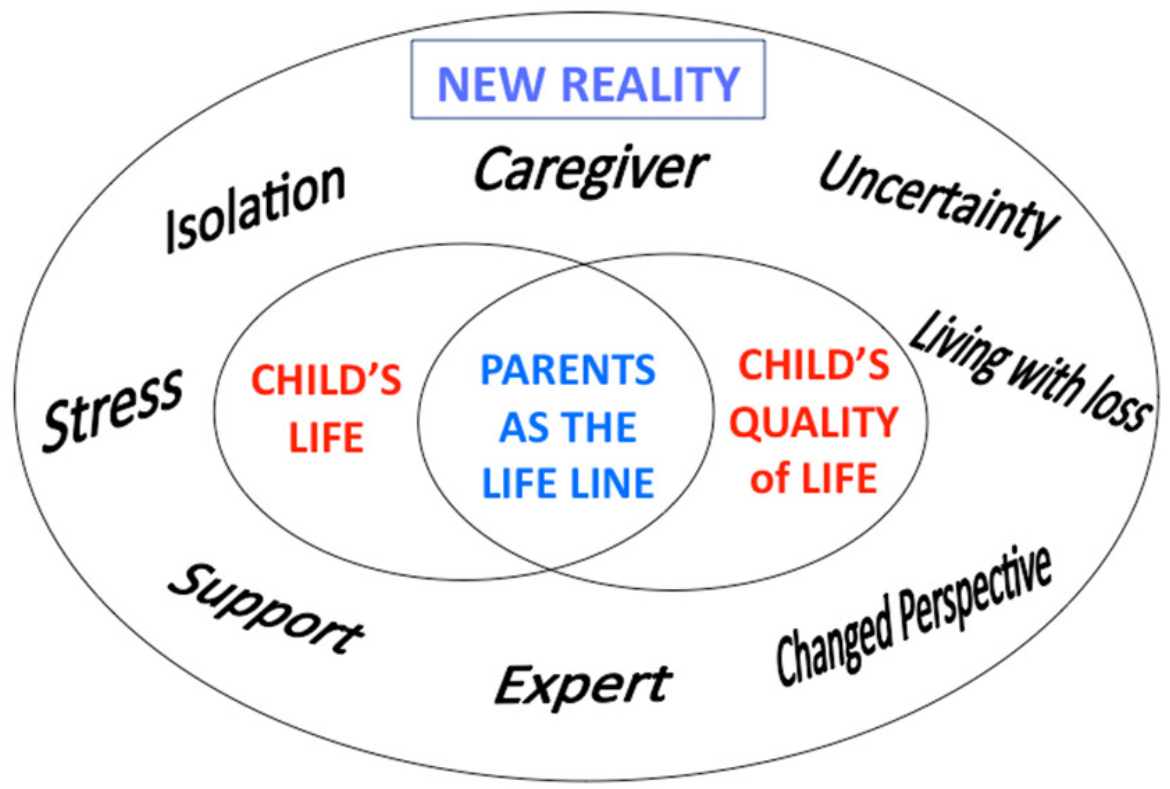

Fig. 1. Parental experience in caring for a child with neuromuscular disease [Mah et al, 2008b]. Reproduced with permission.

Given the emphasis by parents on providing the best possible care and ensuring optimal HRQOL for their child with NMD, the rest of the family unit's needs including those of the siblings, the spouse, and the primary caregiver tended to become secondary priorities. In addition being their child's primary caregivers, parents also took on the various functions of health care professionals (HCP) such as nursing and respiratory therapy. Given sufficient practice, they soon became experts on their child's care and the child's NMD. For most parents, the demand of caring for their child with NMD was disruptive to family life; they found it hard to spend quality time together. Over time, these demands became part of their normal daily routine. One parent summed up major losses such as friendship, income, privacy, and personal identity. The loss was not solely related to the child's NMD and declining health, but also due the impact of the parents' decision to give up their careers, passions, and personal desires to meet their child's needs. Parents lived with uncertainty in anticipation of future losses and limitations that their children might experience, as well as anxiety as to how their children would react to those losses. 
Despite a recurring sense of loss, many parents opted to look beyond the negatives and focused on the positive aspects of their lives. Most families accepted the reality of caring for their child with NMD, and worked through the experience in order to move forward to live their lives as best they could. Living for the present helped parents to accept their changed lives and to live with the uncertainty that became their "new" normal. Most families also lived with the hope that there would be some improvement, a new treatment, or a cure around the corner that could benefit their children with NMD.

The core of the parental experience can be summarized as "being the lifeline" for their child with NMD Being the "lifeline" symbolized the vital role and the weight of the responsibility that parents had assumed to ensure the survival and well-being of their child with NMD. The core experience conveyed the love and devotion of parents for their child, and their desire for their child to live and to enjoy good quality of life despite the physical and sometimes cognitive limitations. The lifeline also embodied the mutually dependent and nurturing relationship that existed between the parents and their child with NMD. Most parents in this study acknowledged that they were receiving as much or more from their child than what they were giving to their child. Despite the many challenges and hardships these parents dealt with on a daily basis, they could not imagine life without their child, as he/she was also their "lifeline." Therefore, the "lifeline" theme serves as an important reminder to HCP in regards to to the parents' key role in safe guarding their child's life and ensuring their child's quality of life. Awareness of this reciprocal "lifeline" relationship between the parents and the child with NMD should also facilitate the recognition of parents as experts and key partners in decisions related to the child's medical management.

This study also highlights the importance of support from HCP, extended family, and community agencies. As consistent with results by van Kesteren and his colleagues [van Kesteren et al, 2001], families with NMD children requiring continuous assisted ventilation in our study were more likely to experience increased stress, particularly when support was inadequate. Potential gaps in the health care system that were identified by these parents included insufficient funding for essential supportive equipment, lack of appreciation for the "whole" child and the entire family unit, and unavailability of respite workers due to suboptimal wages and manpower shortages in our health regions. Families who perceived a lack of support were burdened with the responsibility of being the sole caregivers for their child, and might therefore be at higher risk for stress-related illnesses and adverse psychological outcomes. Specific strategies to improve support for these families will require greater coordination of services, reliable access to respite personnel, and an individualized approach to address each family's needs and priorities.

\section{Family-centered care approach to DMD}

The management of boys with DMD may benefit from a family centered model of care that promotes communication and consensus-building among HCP, administrative staff, and community agencies, with each family being an integral part of the interdisciplinary team [Ivey et al, 1988]. Accordingly, family-centered practice perceives "the entire family as the unit of attention" and provides services in a collaborative fashion based on informed choice, in accordance with each individual family's strengths, needs, and goals. Family centered care (FCC) acknowledges the importance of the family in meeting the physical, psychosocial, and developmental needs of children [Bissell et al, 2004; American Academy 
of Pediatrics, 2004]. The premise for a family-centered model of service delivery is based on the assumption that "parents know their children best and they want the best for their children"[Bamm \& Rosenbaum, 2008]. An essential element of this model of care is to align the clinical practice with the needs of patients and families, as each family may not want the same degree of participation in their health care due to social and cultural factors [Boon et al, 2004; Deber, 1994a; Deber, 1994b; Deber et al, 1996]. As needs may change over time, it is also important to identify the support needs of individuals and families at different stages of the illness [Trivette et al, 1993]. In addition, children thrive within a supportive family and community environment. Thus, the purpose of FCC is to empower the caregivers and to enhance their well-being in order to maximize positive health and developmental outcomes for their children. This model of care reflects a paradigm shift away from the traditional paternalistic model of physician-patient relationship towards an equal partnership between families and HCP in order to arrive at mutually agreed goals. Early anticipatory guidance may help families cope with disease progression (see Table 4) [Dawson \& Kristjanson, 2003].

The main guiding principle of FCC is to align the clinical practice with the needs of the families and to enable each family to be involved in making decisions for their child's health care. In order to accomplish this goal, special attention should be paid to the service providers' interactions with the families as well as the organizational approach to service delivery. From an interpersonal level, the practice of FCC will require the service providers to: a) show respect for the family's perspective, values, and cultural diversity; b) identify family strengths, needs, and priorities on an on-going basis; c) provide information about their child's condition in a way that matches the family's needs; d) involve families in decision-making; and e) develop services that are flexible to the needs of individual families. From an organizational or institutional level, the delivery of family centered services will require the managers and policy-makers to provide: a) service coordination and integration within and between sectors; b) expedients for family-to-family support; c) family-friendly physical environments; d) high quality general and illness-specific information; and e) opportunities for family involvement in decision-making at all levels of the organization.

Previous studies of FCC effectiveness have focused primarily on the impact on FCC practices on parental outcomes, such as a reduction in caregivers' stress, an improvement in their overall well-being, or an increase in satisfaction with care [Dunst et al, 2007]. In 2008, Dempsey and Keen summarized the findings of 35 studies published during 1993 to 2004 pertaining to the processes and outcomes of family centered services for children with disabilities [Dempsey et al, 2009]. Most of these studies examined health care providers' interpersonal strategies such as the provision of help-giving practices or other processes of care. The impact on parent outcomes included: a) a mild to moderate increase in psychological well-being; b) an increase sense of empowerment; and c) a greater degree of satisfaction with services. The effects on child outcomes were less evident, and included some (albeit inconsistent) degree of improvement in child development or health. Recently, Moore et al examined the relationship of processes of care to children's HRQOL [Moore et al, 2009]. The study included 187 caregivers of children from the pediatric neurosciences clinics at the Alberta Children's Hospital; 44 (24\%) of these children suffered from a neuromuscular disease. FCC was found to be a significant predictor of parent-reported children's physical, psychosocial, and total HRQOL, independent of the illness severity. The provision of family-centred care practices by service providers had a positive impact on the quality of life of children with neurological disorders. 


\begin{tabular}{|c|c|c|c|}
\hline $\begin{array}{l}\text { Key Stages \& } \\
\text { FCC Strategies }\end{array}$ & $\begin{array}{l}\text { Early to late ambulatory stage } \\
\text { ( } 4 \text { to } 10 \text { years old) }\end{array}$ & $\begin{array}{l}\text { Early non-ambulatory } \\
\text { stage (10 to } 16 \text { years old) }\end{array}$ & $\begin{array}{l}\text { Late non-ambulatory } \\
\text { stage ( }>16 \text { years old) }\end{array}$ \\
\hline \multirow{5}{*}{$\begin{array}{l}\text { Family } \\
\text { knowledge: } \\
\text { Show respect for } \\
\text { the family's } \\
\text { perspective \& } \\
\text { expertise }\end{array}$} & Discuss: & \multirow{9}{*}{$\begin{array}{l}\text { Discuss: } \\
\text { Nutrition } \\
\text { Complications of DMD } \\
\text { (scoliosis, cardiac, and } \\
\text { respiratory) } \\
\text { Complications of } \\
\text { corticosteroids } \\
\text { Symptoms of nocturnal } \\
\text { hypoventilation } \\
\text { Options for long-term } \\
\text { ventilation assistance } \\
\text { (i.e. BiPAP, CPAP) } \\
\text { Medical management of } \\
\text { cardiomyopathy if present } \\
\text { School \& social support } \\
\text { Respite \& financial issues } \\
\text { Adolescent needs \& } \\
\text { quality of life } \\
\text { Review previous topics }\end{array}$} & Discuss: \\
\hline & DMD natural history \& genetics & & Transition to adult care \\
\hline & Role of corticosteroids & & Options for long-term \\
\hline & Research studies & & ventilation support \\
\hline & \multirow{2}{*}{$\begin{array}{l}\text { Genetic counselling referral } \\
\text { Carrier testing if indicated }\end{array}$} & & \multirow{2}{*}{$\begin{array}{l}\text { Nutritional support } \\
\text { (i.e. gastrostromy tube) }\end{array}$} \\
\hline & & & \\
\hline $\begin{array}{l}\text { Identify family's } \\
\text { needs, strengths, } \\
\mathcal{E} \text { priorities on an } \\
\text { on-going basis }\end{array}$ & $\begin{array}{l}\text { Provide written material, } \\
\text { websites \&peer support } \\
\text { information }\end{array}$ & & $\begin{array}{l}\text { End-of-life counseling } \\
\text { and advance medical } \\
\text { directive }\end{array}$ \\
\hline $\begin{array}{l}\text { Provide } \\
\text { information that } \\
\text { matches the } \\
\text { family's needs }\end{array}$ & $\begin{array}{l}\text { Muscular Dystrophy } \\
\text { Association (MDA) \& Parent } \\
\text { Project contact information }\end{array}$ & & \multirow[t]{2}{*}{$\begin{array}{l}\text { Review previous } \\
\text { topics }\end{array}$} \\
\hline $\begin{array}{l}\text { Facilitate family- } \\
\text { to-family support }\end{array}$ & & & \\
\hline \multirow{4}{*}{$\begin{array}{l}\text { Professional } \\
\text { Support } \\
\text { Involve families in } \\
\text { decision-making } \\
\text { Develop services } \\
\text { that are flexible to } \\
\text { the needs of } \\
\text { individual families }\end{array}$} & $\begin{array}{l}\text { Medical consultations: } \\
\text { Genetics }\end{array}$ & $\begin{array}{l}\text { Medical consultations } \\
\text { (as before, plus) }\end{array}$ & \multirow[t]{5}{*}{$\begin{array}{l}\text { Medical consultations } \\
\text { (as before) }\end{array}$} \\
\hline & Respirology & Endocrinology & \\
\hline & $\begin{array}{l}\text { Orthopaedics (night splints, } \\
\text { scoliosis) }\end{array}$ & $\begin{array}{l}\text { (osteoporosis, } \\
\text { bisphosphonate therapy) }\end{array}$ & \\
\hline & $\begin{array}{l}\text { Cardiology } \\
\text { Neurology / Physiatry } \\
\text { Ophthalmology (cataracts) }\end{array}$ & $\begin{array}{l}\text { Teach: } \\
\text { Chest physiotherapy to } \\
\text { family }\end{array}$ & \\
\hline $\begin{array}{l}\text { Provide service } \\
\text { coordination and } \\
\text { integration within } \\
\text { and between } \\
\text { sectors }\end{array}$ & $\begin{array}{l}\text { Allied health support: } \\
\text { Clinic Nurse - Dietician } \\
\text { Physiotherapist - Psychologist } \\
\text { Occupational therapy } \\
\text { Social worker } \\
\text { MDA community liaison }\end{array}$ & $\begin{array}{l}\text { Breath stacking, cough assist } \\
\text { Seating for wheelchair } \\
\text { Passive \& active exercises }\end{array}$ & \\
\hline \multirow{9}{*}{$\begin{array}{l}\text { Medical } \\
\text { Therapy: } \\
\text { Provide high } \\
\text { quality general } \\
\text { and illness-specific } \\
\text { information } \\
\text { Establish } \\
\text { opportunities for } \\
\text { family } \\
\text { involvement in } \\
\text { decision-making at } \\
\text { all levels of the } \\
\text { organization }\end{array}$} & Immunizations: & $\underline{\text { Review previous topics }}$ & \multirow{9}{*}{$\begin{array}{l}\text { Review previous } \\
\text { topics }\end{array}$} \\
\hline & $\begin{array}{l}\text { Varicella vaccine } \\
\text { Pneumococcal vaccine }\end{array}$ & Interventions (as required): & \\
\hline & Influenza vaccine & Angiotensin converting & \\
\hline & $\frac{\text { Corticosteroids }}{\text { Deflazacort }(0.9 \mathrm{mg} / \mathrm{kg} / \mathrm{d}) \text { or }}$ & $\begin{array}{l}\text { enzyme inhibitor and/ } \\
\text { or beta-blocker }\end{array}$ & \\
\hline & Prednisone $(0.75 \mathrm{mg} / \mathrm{kg} / \mathrm{d})$ & (cardiomyopathy) & \\
\hline & $\begin{array}{l}\text { Physiotherapy: } \\
\text { Passive stretching, night splints }\end{array}$ & $\begin{array}{l}\text { Diuretics (congestive heart } \\
\text { failure) }\end{array}$ & \\
\hline & \multirow{2}{*}{$\begin{array}{l}\text { Bone health: } \\
\text { Calcium supplementation } \\
\text { Vitamin D supplementation }\end{array}$} & $\begin{array}{l}\text { Antibiotics (respiratory } \\
\text { tract infections) }\end{array}$ & \\
\hline & & Sitting ankle-foot orthosis & \\
\hline & $\begin{array}{l}\text { Other: } \\
\text { Behavioral intervention } \\
\text { Weight management }\end{array}$ & $\begin{array}{l}\text { Scoliosis surgery (pre-op } \\
\text { Cardiology, Respirology \& } \\
\text { Anaesthesiology consults) }\end{array}$ & \\
\hline
\end{tabular}




\begin{tabular}{|c|c|c|c|}
\hline $\begin{array}{l}\text { Key Stages \& } \\
\text { FCC Strategies }\end{array}$ & $\begin{array}{l}\text { Early to late ambulatory stage } \\
\text { (4 to } 10 \text { years old) }\end{array}$ & $\begin{array}{l}\text { Early non-ambulatory } \\
\text { stage (10 to } 16 \text { years old) }\end{array}$ & $\begin{array}{l}\text { Late non-ambulatory } \\
\text { stage ( }>16 \text { years old) }\end{array}$ \\
\hline \multirow[t]{2}{*}{$\begin{array}{l}\text { Clinical / } \\
\text { Laboratory } \\
\text { Monitoring: } \\
\text { Create family- } \\
\text { friendly physical } \\
\text { environments }\end{array}$} & $\begin{array}{l}\text { Weight, height, \& blood pressure } \\
\text { Formal muscle function \& } \\
\text { strength test } \\
\text { ECG, echocardiogram (every } \\
2 \text { year) } \\
\text { Pulmonary function testing } \\
\text { Wrist x-ray for bone age } \\
\text { Bone densitometry scan }\end{array}$ & $\begin{array}{l}\text { Same as before, except: } \\
\text { ECG, echocardiogram } \\
\text { (yearly) }\end{array}$ & $\underline{\text { Same as before }}$ \\
\hline & 25-hydroxyvitamin D level & $\begin{array}{l}\text { Same as before, plus: } \\
\mathrm{PCO}_{2} \text { measurement } \\
\text { as needed }\end{array}$ & $\underline{\text { Same as before }}$ \\
\hline Clinical review: & 6 to 12 months & 3 to 6 months & 1 to 3 months \\
\hline
\end{tabular}

Table 4. Summary of Family Centred Care (FCC) Strategies for Duchenne Muscular Dystrophy [McMillan et al, 2010]. Reproduced with permission.

Thus, currently available evidence suggests that interpersonal strategies of FCC are positively associated with parental well-being, satisfaction, and empowerment. There is limited evidence of positive impact of family centered services on children's health and development. Further studies are needed to determine the key outcome variables as well as the longer-term effects of FCC strategies on parent and child outcomes. Subsequent studies should also examine if family centered services affect pediatric health outcomes directly or indirectly through improving parent outcomes, and how the practice can be incorporated as standard of care for children with severe neuromuscular disorders such as DMD.

\section{Challenges related to unmet support needs}

Similar to the reports from caregivers of children with other neuromuscular diseases, parents of DMD boys may experience frustration due to poor communication and fragmentation of care within the health care system. It is therefore important for clinicians to understand the priority support needs of individuals with DMD and their families across different stages of the disease. Accordingly, the natural history of DMD can be summarized into five main stages, including: a) the pre-symptomatic phase; b) the early ambulatory phase; c) the late ambulatory phase; d) the early non-ambulatory phase; and e) the late non-ambulatory phase [Weidner, 2005]. The purpose of this next study was to explore the unmet support needs of families of boys with DMD at different stages of the disease. We adapted the Family Needs Survey [Bailey 1990] by adding items specific to DMD, and administered it to a representative sample of parents of boys with DMD from two tertiary pediatric neuromuscular clinics in Canada, a country where health care is publicly funded. We hypothesized that the number of unmet needs might increase over time due to progression of the disease and vary by parental sociodemographic characteristics such as ethnicity or education.

\subsection{Methods}

This was a mixed method study with participation from parents of children and youth with DMD. For the purpose of this study, individuals were considered to have DMD if they fulfilled all of the following criteria: a) onset of weakness before age 5; b) male gender; c) 
evidence of proximal muscle weakness; d) increased serum creatine kinase; and e) confirmed mutation in the dystrophin gene or dystrophic muscle biopsy with marked deficiency in dystrophin immunostaining consistent with a diagnosis of DMD. Families with limited English comprehension or those who were unable to provide informed consent were excluded. Written informed consent from caregivers and assent from children was obtained prior to enrolment. The study was approved by the institutional review boards from the two participating centers.

The Family Needs Survey (FNS) was developed by Bailey and Simeonsson as a parsimonious approach to identify specific family needs and to elicit parents' priorities for services in children with disabilities [Bailey \& Simeonsson, 1990], and it has been adapted for use across different cultures [Chen et al; 1994; Hendriks et al, 2000]. The original version contained 35 self-report items grouped into seven general categories, including the need for: 1) information; 2) family and social support; 3) financial support; 4) explaining to others; 5) child care; 6) professional support; and 7) community services. Parents who indicate "yes," to each item are given a score of 1 , and other responses (no, or not sure) are scored as 0 [Bailey et al, 2004]. Previous studies have indicated strong inter-item reliability, with a reported Cronbach's alpha coefficient of 0.91 for the total score [Sexton et al, 1992]. Good agreement was found between mothers and fathers, and the responses were stable within a six-month period [Bailey \& Simeonsson, 1988]. Permission from the authors was obtained to modify the Family Needs Survey for this study. The DMD Family Needs Survey (DMDFNS) contained an additional 31 items exploring disease specific information and support needs of families caring for individuals with DMD, reflecting current clinical practice guidelines. The maximum score of the DMD Family Needs Survey was 66, with higher scores indicating more unmet needs. In addition, families were asked to rate the importance of each unmet need on a 5-point Likert scale, with a score of 1 indicating a "somewhat important" need, and a score of 5 indicating a "very important" need. The questionnaire also included items on the caregivers' socio-demographic characteristics and their child's current health status.

The DMD-FNS was reviewed by six paediatric neuromuscular clinic staff (including physicians and allied professionals) for content validity, and then piloted with five parents of boys with DMD for input regarding the area of needs, the appropriateness of items on the scale, the wording, and other content issues. Upon completion of the pilot, a cover letter and the revised DMD Family Needs Survey were distributed to the rest of the parents of DMD boys followed at the Alberta Children's Hospital in Calgary, Alberta and the Bloorview Kids Rehab in Toronto, Ontario. Both centers provide care for individuals with DMD in a similar multidisciplinary team setting, including assessments by paediatrics, social work, nursing, occupational therapy, physiotherapy, orthopaedic surgery, dietician, respirology and/or cardiology on the same clinic day [McMillan et al, 2010].

Parents who consented to participating in the study completed the questionnaire on their own and then returned it by mail or in person in a self-addressed and stamped envelope. A minimum sample size of 60 responses from the DMD Family Needs Survey was planned, with at least 10 to 15 families representing each of the four stages of DMD, including: a) at diagnosis (< 8 years); b) near cessation of ambulation (8 - 12 years); c) during adolescence (13 - 18 years); d) at advanced stage of the disease (> 18 years). Descriptive statistics were used to summarize the characteristics of the study participants and their priority support 
needs. Categorical variables were expressed as frequencies and percentages, and bivariate comparisons were made using Pearson's chi-square or Fisher's exact test. Continuous variables were reported as means with standard deviations or as medians with interquartile ranges if the data was skewed, and comparisons were made using unpaired Student's t-tests or one-way analyses of variance. All tests were two-tailed, and p values less than 0.05 were considered to be statistically significant.

In addition, parents who completed the DMD-FNS at the Bloorview Kids Rehab were invited to participate in a focus group meeting. The focus group was an ideal setting to verify the survey results, to explore ideas on how to address the identified priority needs, and to provide mutual support for the participants based on shared experiences [Kitzinger, 1995]. Written consent was obtained prior to the start of the meeting. Discussion from the focus group was audio-recorded and then transcribed verbatim. The analysis was performed in accordance with the phenomenological method of inquiry, by engaging in repeated immersions in the data prior to descriptive coding, and then using topic and analytic codes to identify themes that were central to the parents' experience and needs in caring for their child with DMD [Coffey \& Atkinson, 1996].

\subsection{Results}

A total of 61 (59.8\%) out of 102 eligible families participated in the DMD-FNS. Forty-five (74\%) of the respondents were mothers, and the mean age was 45.3 (standard deviation 7.5, range 32-59) years. Fifty-four (89\%) respondents were married; $49(80 \%)$ respondents had post-secondary education, and the majority (46 families, $75 \%$ ) were from Bloorview Kids Rehab program. The mean age of the boys with DMD was 11.8 (standard deviation 6.4, range 1 - 25) years; they were diagnosed at a mean age of 4.2 (standard deviation 2.3, range 0 to 12$)$ years. Thirty-four (66\%) boys were walking independently, $10(16 \%)$ required the use of bi-level positive airway pressure ventilatory support, and the majority ( 51 boys, $84 \%$ ) were on deflazacort as disease modifying treatment for DMD. There was no significant difference between the study participants and study non-responders in regards to the child's age, ambulatory status, need for assisted ventilation, or use of corticosteroids.

\subsubsection{Unmet family support needs}

The mean DMD-FNS total score was 25.1 (standard deviation 15.0), reflecting a large number of unmet family support needs. Cronbach alpha for the total score was 0.95 , which suggested a high level of inter-item reliability. We found no significant differences between the mean number of needs and the stage of the disease by age group (see Table 5). The categories with the largest numbers of unmet needs overall, and for which a majority of parents expressed unmet needs were related to information, financial, and psychosocial supports. All items that the majority of families (i.e., $>50 \%$ ) indicated were unmet needs are listed in Table 6 . Each of these items had mean Likert rating scores greater than 4, confirming that these were "important" or "very important" needs for the parents. There were no significant differences between the mean number of needs and the child's characteristics such as age, ambulatory status, need for ventilation support, and other co-morbidities such as learning disability, behavioural problems, or scoliosis. Similarly, socio-demographic factors including the parent's age, ethnicity, marital status, education, and place of residence (Ontario versus Alberta) were not associated with significant differences in the mean number of identified needs. 


\begin{tabular}{|c|c|c|c|c|c|c|}
\hline Unmet Needs & $\begin{array}{l}\text { All ages } \\
\left(\mathrm{n}=57^{*}\right)\end{array}$ & $\begin{array}{l}<8 \text { yrs } \\
(\mathrm{n}=19)\end{array}$ & $\begin{array}{c}8-12 \text { yrs } \\
(n=14)\end{array}$ & $\begin{array}{c}13-18 \text { yrs } \\
(n=8)\end{array}$ & $\begin{array}{l}>18 \text { yrs } \\
(n=16)\end{array}$ & p value \\
\hline \multicolumn{7}{|l|}{ Information } \\
\hline Mean (SD†) & $11.5(6.4)$ & $11.8(6.8)$ & $10.8(6.2)$ & $14.6(5.1)$ & $10.2(6.6)$ & 0.44 \\
\hline \multicolumn{7}{|c|}{ Family and social support } \\
\hline Mean (SD) & $4.1(3.8)$ & $3.3(4.0)$ & $4.6(3.2)$ & $4.6(3.4)$ & $4.4(4.3)$ & 0.75 \\
\hline \multicolumn{7}{|c|}{ Financial support } \\
\hline $\begin{array}{l}\text { Mean (SD) } \\
\text { Explaining to o }\end{array}$ & $3.5(3.0)$ & $2.8(3.5)$ & $3.9(2.2)$ & $3.7(3.0)$ & $4.0(3.2)$ & 0.63 \\
\hline Mean (SD) & $1.4(1.5)$ & $1.9(1.7)$ & $1.3(1.3)$ & $1.2(0.7)$ & $0.8(1.6)$ & 0.17 \\
\hline \multicolumn{7}{|l|}{ Child care } \\
\hline Mean (SD) & $1.1(0.9)$ & $0.9(1.1)$ & $1.4(0.6)$ & $1.0(0.8)$ & $1.0(0.9)$ & 0.56 \\
\hline \multicolumn{7}{|c|}{ Professional support } \\
\hline Mean (SD) & $1.3(1.8)$ & $1.3(2.4)$ & $1.1(1.1)$ & $1.2(1.4)$ & $1.7(1.8)$ & 0.82 \\
\hline \multicolumn{7}{|c|}{ Community services } \\
\hline Mean (SD) & $2.0(1.3)$ & $2.2(1.5)$ & $1.6(1.1)$ & $2.0(1.2)$ & $2.2(1.4)$ & 0.51 \\
\hline \multicolumn{7}{|l|}{ Total } \\
\hline Mean (SD) & 24.9 (15.2) & $24.2(18.3)$ & $24.6(13.2)$ & 28.5 (10.7) & $24.4(15.8)$ & 0.92 \\
\hline
\end{tabular}

* Four had incomplete responses and were removed from the analyses of variance

tSD referred to standard deviation of the mean

Table 5. Comparison of total mean number of unmet needs by different age categories of boys with DMD

\begin{tabular}{lcc}
\hline & Percent & $\begin{array}{c}\text { Number of } \\
\text { Respondents }\end{array}$ \\
\hline General Information Needs & $74 \dagger$ & 61 \\
Information about services presently available for my child & $74 \dagger$ & 61 \\
Information about services for parents and siblings* & $64 \dagger$ & 59 \\
How my child will grow and develop & 62 & 61 \\
Information about services my child might receive in the future & 59 & 61 \\
Reading materials or websites about other families who have a child & & \\
like mine & & 60 \\
DMD Specific Information Needs & $66 \dagger$ & 61 \\
Improving my child's bone health* & 62 & 61 \\
Issues related to spinal deformity or scoliosis* & 61 & 60 \\
Helping my child to be more physically active* & 61 \\
The diagnosis of DMD and what it means for my child and my family* & 54 & 60 \\
Stretching exercises, night splints or orthotics* & 54 & 61 \\
Issues related to my child's lung function* & 54 & 60 \\
Use of corticosteroids and/or other treatment* & 51 & \\
Use of bi-level positive airway pressure or other assisted breathing & 51 & \\
devices* & & \\
\hline
\end{tabular}




\begin{tabular}{lcc}
\hline & Percent & $\begin{array}{c}\text { Number of } \\
\text { Respondents }\end{array}$ \\
\hline $\begin{array}{l}\text { Financial Support Needs } \\
\begin{array}{l}\text { Paying for medications, treatment or equipment that my child needs } \\
\text { Paying for complementary or alternative therapies for my child* }\end{array}\end{array}$ & 56 & 61 \\
$\begin{array}{l}\text { Paying for expenses related to modifications in our home and or } \\
\text { vehicle* }\end{array}$ & 51 & 61 \\
$\begin{array}{l}\text { Psychosocial Support Needs } \\
\begin{array}{l}\text { Meeting and talking with other parents who have a child like mine } \\
\text { Helping my child to make new friends* }\end{array}\end{array}$ & $67 \dagger$ & 61 \\
$\begin{array}{l}\text { Locating babysitters or respite care providers who are willing and } \\
\text { able to care for my child }\end{array}$ & 56 & 61 \\
\hline
\end{tabular}

* New items specific for DMD are marked with an asterix

t Indicated the top five most frequently expressed needs in the DMD Family Needs Survey

Table 6. Unmet information, financial and psychosocial support needs identified by the majority of the parents of boys with DMD

\subsubsection{Needs across stages of the illness}

Participants of the 3-hour DMD focus group meeting included eight (3 dads, 5 moms) parents of boys (aged 6 to 21 years) with DMD. The main interview questions were: 1) When you first learned your son had DMD, what did you need? 2) How did your needs change over time? The responses of participants confirmed that information, financial support, and psychosocial supports were important needs across the course of the illness. However, the types and intensity of supports needed varied according to the stage of the illness, and according to each family situation. Themes emerged for the different stages of the illness, and these are described below.

\subsubsection{Needs at diagnosis}

Parents described their needs for information and emotional support at the time of diagnosis. They emphasized that the diagnosis should be given by a knowledgeable and empathetic physician, and immediate psychosocial support should be available, preferably by connecting with other parents who had gone through the same experience. However, some families were not ready to discuss their information needs soon after the diagnosis, due to the overwhelming sense of grief. One parent expressed it as a need to "take the time to grieve over it first." The ideal time for discussion might occur much later for these families.

\subsubsection{Needs during adolescence}

This period is marked by progressive loss of mobility for boys with DMD. Therefore it is not surprising that a dominant need during this time is financial assistance for equipment, transportation, and modifications to the family home. Parents identified their struggles with bureaucracy and the lack of financial support from public and private sources. They indicated that there was a lack of coordination and information about services and financial support, as articulated by one parent: "There isn't a single body that can sort of bring all of these 
things together and say, 'okay look, this is where you need to go; this is what you need to do, and these are the people you need to get money from ... All those agencies, none of them talked to each other." Parents talked about how this forced them into an advocacy role in order to get necessary supports and services. They reported that lack of coordination and the subsequent need for them to act as advocates resulted in much wasted time, time that could be spent caring for their family.

\subsubsection{Needs at advanced stage of the disease}

At this point, parents' needs for information and psychosocial supports seemed to decrease. Parents of young adults with DMD described how they had accepted the reality that their child could die soon. Despite the relentless progression of the disease, these parents were able to offer meaningful support, encouragement, and practical advice to younger families, as summed up by one parent: "I think it really teaches you that ... the moment is the most important; this day is wonderful, ... you learn a lot from your child actually, because they have this sort of innate strength that is quite remarkable."

Across all the stages parents indicated that they were very interested in participating in research, particularly if it would eventually lead to a cure. Those that had been actively involved in research activities or fundraising indicated that it gave them hope for the future, and helped them feel as if they were helping others.

\section{Discussion}

Consistent with previous research, our study found that parents of boys with DMD have many unmet needs, despite living in a country like Canada where health care is publically funded [Abresch et al, 1998; Buchanan et al, 1979; Firth et al, 1983]. Their needs may be unmet due to a lack of awareness or inability of available resources to adequately target their children needs. In this study we did not find a significant difference in the mean number of unmet needs across key stages of the illness, which suggests that families have needs throughout the course of the illness. As well, there was no significant difference in the mean number of needs by disease severity or parental socio-demographic characteristics.

Although the number of needs did not vary, the results of the group interview indicated that types of needs within the categories of information, financial, and psychosocial supports varied according to the stage of the illness and family situation. By using the DMD-FNS during clinic visits, health care professionals may be in a better position to understand each family's unique priority needs and strengths, instead of having to second guess what they might be or be influenced by clinician's personal bias [Gibson, 2001; Kinali et al, 2007]. The revised DMD-FNS that was used in this study incorporates topics specific to the care of individuals with DMD, and therefore may serve as an ideal prompt for parents to discuss these issues during their child's regular clinic visits. For example, it is important to acknowledge the frequent use of complementary or alternative therapies and the resultant financial burden on families of children with severe neurological disorders such as DMD [Soo et al, 2005]. The parents rated each identified need as very important, so the Likert scale did not provide additional information and we recommend it be removed from subsequent needs surveys for this population. 
As the families' ability to cope during the course of the illness may be modified by their interaction with HCP, a major implication of our results is that HCP should make it a priority to provide information to families about DMD that is accessible and customized to their situation [Fitzpatrick \& Barry, 1986; Steele, 2002]. A second priority pertains to the coordination of community based services to assist families to access financial supports for equipment and housing modifications in a timely fashion. A third priority is the provision of ongoing psychosocial supports, which may include individual counselling or family peer support programs.

A limitation of the DMD-FNS study relates to the small sample size. The mixed methodology compensated for the low numbers by using a group interview to verify and extend the results of the mailed survey. Future studies could recruit a larger sample to further explore differences across stages of the illness and across family demographics. A second limitation was that we relied on parent report and did not directly survey older children and youth for their perceived needs. During the pilot we found that most boys in the initial pilot phase of the study did not have the ability to work independently through a lengthy questionnaire like the DMD Family Needs Survey. However, previous research indicates that the needs of adolescents may vary significantly from their parents, and it is important to give the youth a voice [Mah et al, 2006]. Future studies could use an abbreviated DMD youth survey to clarify the changing needs of adolescents and young adults with DMD over time. Lastly, our survey was limited to families of boys who were currently living with DMD and may not provide a complete picture of family needs at the final stage of the illness. It may be helpful to interview families after their child has passed away.

Parents who participated in the group interview reflected that they appreciated the opportunity to share and to meet each other and were glad to participate in a research project. They indicated that participation in research projects gave them hope for the future. Based on this experience we recommend that parents of boys with DMD be included in future research initiatives as they have an important perspective and stake in the outcomes of such research.

\section{Implications for clinical practice}

Individuals with DMD and their families have to adjust to many challenges because of the progressive nature of the disease. The family resilience framework developed by Dr. Froma Walsh, Co-Founder and Co-Director of the Chicago Center of Family Health, can be applied to the neuromuscular population to serve as a guide to target and strengthen key processes that will encourage optimal adaptation of children and adolescents with DMD [Walsh, 2003]. Resilience involves a dynamic process that enables individuals "to withstand and rebound from disruptive life challenges, becoming strengthened, and more resourceful" [Rolland \& Walsh, 2006]. Resilience is not innate or restricted to certain people only, and it can be learned over time. A resilience framework for supporting boys with DMD targets on strengths rather than problems, partnership instead of paternalism, and families (rather than the clinicians) as the center of attention. It acknowledges the family as the unit of operation, with tremendous potentials for growth and transformation. Each family in turn has unique perspectives, resources, strengths, and challenges. 
According to Walsh, the key processes in family resilience focus on: 1) beliefs system, including making meaning of adversity, contextualizing distress, having a positive outlook, and developing transcendence and spirituality; 2) organization pattern (in partnership with community agencies, schools, healthcare, workplace and other larger systems) that provides flexibility, connectedness, social and economic resources; 3) communication strategy, with emphasis on clarity, open emotional expression, and collaborative problem-solving. Relational attributes of this framework include peers, extended family members, and other mentors. The goal of the resilience framework is to promote strong and enduring relationships, to help shape and sustain them to meet life challenges.

In practice, integration of the beliefs system should include: a) assessing family network and their prior experience; b) providing peers and extended family support; c) establishing routines for young children and their siblings; and d) offering genetic counselling to alleviate parental guilt. Positive outlook can be fostered by a) presenting research and current available supporting treatment as opportunities for hope; b) affirming the child's potentials and encouraging the family to look forward to college and beyond; and c) celebrating successes, initiatives, and perseverance, using life examples such as Jesse's Journey and other parent support organizations. In regards to transcendence and spirituality, it is helpful for family to: a) see the bigger picture and purpose, as one family said that they were "chosen to live a better life"; b) embrace spiritual domain of being human, which includes suffering and injustice; c) learn to living with paradox, to make the best out of the worst of times; and d) offer spiritual and inspirational support as necessary.

Using Walsh's conceptual approach, clinicians may be in a better position to help adolescents and their families to gain insight about their illness experience, to appreciate the strengths and vulnerabilities of each family member and the emerging adolescent developmental needs, and to recognize key family beliefs that explain their illness narratives and relationships with healthcare professionals. Clinicians can also foster the development of resilience through their direct interactions with DMD patients and their families. The discussion regarding the diagnosis and management of DMD should take place with both the child/adolescent and parents present, and they should be encouraged to participate in all treatment decisions. The treating physician should provide written information about the illness and realistic expectations regarding potential benefits of potentially new diseasemodifying therapies. Financial resources including funding for adaptive equipments should be offered regardless of parental employment status or family income.

Parents should encourage their teenagers to meet age-appropriate developmental goals, including gradual transfer of decision-making authority over time. A resilience-oriented approach also draws upon extended family and peer resources as potential mentors and positive role models in mediating adolescent adjustment to DMD. Clinicians can help families resolve conflicts, identify coping strategies, develop realistic goals, and seek help when needed. Periodic family meetings and multidisciplinary consultations for anticipated transitions, including going away for college and/or transfer to adult services, can facilitate proactive planning and alleviate unnecessary anxiety.

\section{Conclusion}

DMD is a challenging chronic disease that requires multidisciplinary collaboration of healthcare professionals and individualized treatment approach for the adolescent patients 
and their families. The modified Family Needs Survey for DMD is a useful tool for needs assessment, continuing dialogue with families, and tailoring services to address individual families' needs. It may be used as part of a family-centered approach to the care of boys with $\mathrm{DMD}$, in order to promote family resilience and their increase their capacity to deal with the challenges related to this devastating disease.

\section{Acknowledgements}

The authors would like to thank the families who participated in the research studies, the contribution of Dr. Melanie Moore, other collaborators, research assistants, and the paediatric neuromuscular clinic staff in Calgary and Toronto for their on-going support. Funding was provided in part by the Alberta Center for Child, Family, and Community Research, the Stichting Porticus Foundation, the Cooperative International Neuromuscular Research Group, and the Alberta Children's Hospital Foundation. The Duchenne muscular dystrophy Family Needs Survey (DMD-FNS) is available by request.

\section{References}

Aartsma-Rus, A., Van Deutekom, J. C., Fokkema, I. F., Van Ommen, G. J., \& Den Dunnen, J. T. (2006). Entries in the Leiden Duchenne muscular dystrophy mutation database: An overview of mutation types and paradoxical cases that confirm the readingframe rule. Muscle \& Nerve, 34(2), 135-44.

Abidin, R. R. (1983). Parenting stress and the utilization of pediatric services. Children's Health Care: Journal of the Association for the Care of Children's Health, 11(2), 70-3.

Abresch, R. T., Seyden, N. K., \& Wineinger, M. A. (1998). Quality of life. Issues for persons with neuromuscular diseases. Physical Medicine and Rehabilitation Clinics of North America, 9(1), 233-48.

Amenta, A. R., Yilmaz, A., Bogdanovich, S., McKechnie, B. A., Abedi, M., Khurana, T. S., \& Fallon, J. R. (2011). Biglycan recruits utrophin to the sarcolemma and counters dystrophic pathology in mdx mice. Proceedings of the National Academy of Sciences of the United States of America, 108(2), 762-7.

American Academy of Pediatrics Committee on Hospital Care (2003). Family-Centered care and the pediatrician's role. Pediatrics, 112(3 Pt 1), 691-7.

American Academy of Pediatrics Section on Cardiology and Cardiac Surgery. (2005). Cardiovascular health supervision for individuals affected by Duchenne or Becker muscular dystrophy. Pediatrics, 116(6), 1569-73.

Bach, J. R., \& Martinez, D. (2011). Duchenne muscular dystrophy: Continuous noninvasive ventilatory support prolongs survival. Respiratory Care, 56(6), 744-50.

Bailey, D. B., Hebbeler, K., Scarborough, A., Spiker, D., \& Mallik, S. (2004). First experiences with early intervention: A national perspective. Pediatrics, 113(4), 887-96.

Bailey, D B., \& Simeonsson, R. J. (1988). Assessing needs of families with handicapped infants. Journal of Special Education, 22(1), 117-127.

Bailey, D. B., \& Simeonsson, R. J. (1990). Family Needs Survey. Frank Porter Graham Child Development Center Chapel Hill, NC: University of North Carolina; Available from URL:

http://www.fpg.unc.edu/ publicationsoffice/pdfs/familyneedssurvey.pdf. 
Bamm, E. L., \& Rosenbaum, P. (2008). Family-Centered theory: Origins, development, barriers, and supports to implementation in rehabilitation medicine. Archives of Physical Medicine and Rehabilitation, 89(8), 1618-24.

Baskin, B., Banwell, B., Khater, R. A., Hawkins, C., \& Ray, P. N. (2009). Becker muscular dystrophy caused by an intronic mutation reducing the efficiency of the splice donor site of intron 26 of the dystrophin gene. Neuromuscular Disorders: NMD, 19(3), 189-92.

Baxter, P. (2006). Treatment of the heart in Duchenne muscular dystrophy. Developmental Medicine and Child Neurology, 48(3), 163.

Biggar, W. D., Gingras, M., Fehlings, D. L., Harris, V. A., \& Steele, C. A. (2001). Deflazacort treatment of Duchenne muscular dystrophy. The Journal of Pediatrics, 138(1), 45-50.

Birnkrant, D. J., Bushby, K. M., Amin, R. S., Bach, J. R., Benditt, J. O., Eagle, M., . . Kravitz, R. M. (2010). The respiratory management of patients with Duchenne muscular dystrophy: A DMD care considerations working group specialty article. Pediatric Pulmonology, 45(8), 739-48.

Bissell, P., May, C. R., \& Noyce, P. R. (2004). From compliance to concordance: Barriers to accomplishing a re-framed model of health care interactions. Social Science $\mathcal{E}$ Medicine (1982), 58(4), 851-62.

Boon, H., Verhoef, M., O'Hara, D., \& Findlay, B. (2004). From parallel practice to integrative health care: A conceptual framework. BMC Health Services Research, 4(1), 15.

Buchanan, D. C., LaBarbera, C. J., Roelofs, R., \& Olson, W. (1979). Reactions of families to children with Duchenne muscular dystrophy. General Hospital Psychiatry, 1(3), 262-9.

Bushby, K., Muntoni, F., Urtizberea, A., Hughes, R., \& Griggs, R. (2004). Report on the 124th ENMC international workshop. Treatment of Duchenne muscular dystrophy; defining the gold standards of management in the use of corticosteroids. 2-4 April 2004, Naarden, the Netherlands. Neuromuscular Disorders: NMD, 14(8-9), 526-34.

Bushby, K., Finkel, R., Birnkrant, D. J., Case, L. E., Clemens, P. R., Cripe, L., . . DMD Care Considerations Working Group. (2010). Diagnosis and management of Duchenne muscular dystrophy, part 1: Diagnosis, and pharmacological and psychosocial management. Lancet Neurology, 9(1), 77-93.

Bushby, K., Finkel, R., Birnkrant, D. J., Case, L. E., Clemens, P. R., Cripe, L., . . DMD Care Considerations Working Group. (2010). Diagnosis and management of Duchenne muscular dystrophy, part 2: Implementation of multidisciplinary care. Lancet Neurology, 9(2), 177-89.

Chau, N., Daler, S., Andre, J. M., \& Patris, A. (1994). Inter-rater agreement of two functional independence scales: The functional independence measure (FIM) and a subjective uniform continuous scale. Disability and Rehabilitation, 16(2), 63-71.

Chen, J., \& Simeonsson, R. J. (1994). Child disability and family needs in the People's Republic of China. International Journal of Rehabilitation Research. Internationale Zeitschrift Für Rehabilitationsforschung. Revue Internationale De Recherches De Réadaptation, 17(1), 25-37.

Chen, Y. W., Zhao, P., Borup, R., \& Hoffman, E. P. (2000). Expression profiling in the muscular dystrophies: Identification of novel aspects of molecular pathophysiology. The Journal of Cell Biology, 151(6), 1321-36.

Coffey, A., Atkinson, P (1996). Making sense of qualitative data: Complementary Strategies. Thousand Oaks, CA: Sage. 
Dawson, S., \& Kristjanson, L. J. (2003). Mapping the journey: Family carers' perceptions of issues related to end-stage care of individuals with muscular dystrophy or motor neurone disease. Journal of Palliative Care, 19(1), 36-42.

Deber, R. B. (1994). Physicians in health care management: 7. The patient-physician partnership: Changing roles and the desire for information. CMAJ : Canadian Medical Association Journal = Journal De L'association Medicale Canadienne, 151(2), 171-6.

Deber, R. B. (1994). Physicians in health care management: 8. The patient-physician partnership: Decision making, problem solving and the desire to participate. CMAJ: Canadian Medical Association Journal = Journal De L'association Medicale Canadienne, 151(4), 423-7.

Deber, R. B., Kraetschmer, N., \& Irvine, J. (1996). What role do patients wish to play in treatment decision making? Archives of Internal Medicine, 156(13), 1414-20.

Dempsey, I., Keen, D., Pennell, D., O'Reilly, J., \& Neilands, J. (2009). Parent stress, parenting competence and family-centered support to young children with an intellectual or developmental disability. Research in Developmental Disabilities, 30(3), 558-66.

Dunst, C. J., Trivette, C. M., \& Hamby, D. W. (2007). Meta-Analysis of family-centered helpgiving practices research. Mental Retardation and Developmental Disabilities Research Reviews, 13(4), 370-8.

Emery, A. E. (1991). Population frequencies of inherited neuromuscular diseases--a world survey. Neuromuscular Disorders : NMD, 1(1), 19-29.

Fairclough, R. J., Bareja, A., \& Davies, K. E. (2011). 2010 Joan Mott prize lecture: Progress in therapy for Duchenne muscular dystrophy. Experimental Physiology., 96(11), 1101-13.

Finder, J. D., Birnkrant, D., Carl, J., Farber, H. J., Gozal, D., Iannaccone, S. T., . . . American Thoracic Society. (2004). Respiratory care of the patient with Duchenne muscular dystrophy: ATS consensus statement. American Journal of Respiratory and Critical Care Medicine, 170(4), 456-65.

Firth, M., Gardner-Medwin, D., Hosking, G., \& Wilkinson, E. (1983). Interviews with parents of boys suffering from Duchenne muscular dystrophy. Developmental Medicine and Child Neurology, 25(4), 466-71.

Fitzpatrick, C., Barry, C., \& Garvey, C. (1986). Psychiatric disorder among boys with Duchenne muscular dystrophy. Developmental Medicine and Child Neurology, 28(5), 589-95.

Fitzpatrick, C., \& Barry, C. (1986). Communication within families about Duchenne muscular dystrophy. Developmental Medicine and Child Neurology, 28(5), 596-9.

Gibson, B. (2001). Long-Term ventilation for patients with Duchenne muscular dystrophy: Physicians' beliefs and practices. Chest, 119(3), 940-6.

Griggs, R. C., Moxley, R. T., Mendell, J. R., Fenichel, G. M., Brooke, M. H., Pestronk, A., \& Miller, J. P. (1991). Prednisone in Duchenne dystrophy. A randomized, controlled trial defining the time course and dose response. Clinical investigation of Duchenne dystrophy group. Archives of Neurology, 48(4), 383-8.

Hendriks, A. H., De Moor, J. M., Oud, J. H., \& Franken, W. M. (2000). Service needs of parents with motor or multiply disabled children in Dutch therapeutic toddler classes. Clinical Rehabilitation, 14(5), 506-17.

Hoffman, E. P., Brown, R. H., \& Kunkel, L. M. (1987). Dystrophin: The protein product of the Duchenne muscular dystrophy locus. Cell, 51(6), 919-28. 
Ivey, S. L., Brown, K. S., Teske, Y., \& Silverman, D. (1988). A model for teaching about interdisciplinary practice in health care settings. Journal of Allied Health, 17(3), 189-95.

Kinali, M., Main, M., Eliahoo, J., Messina, S., Knight, R. K., Lehovsky, J., . . M Muntoni, F. (2007). Predictive factors for the development of scoliosis in Duchenne muscular dystrophy. European Journal of Paediatric Neurology: EJPN : Official Journal of the European Paediatric Neurology Society, 11(3), 160-6.

Kinali, M., Manzur, A. Y., Mercuri, E., Gibson, B. E., Hartley, L., Simonds, A. K., \& Muntoni, F. (2006). UK physicians' attitudes and practices in long-term non-invasive ventilation of Duchenne muscular dystrophy. Pediatric Rehabilitation, 9(4), 351-64.

Kitzinger, J. (1995). Qualitative research. Introducing focus groups. BMJ (Clinical Research Ed.), 311(7000), 299-302.

Koenig, M., Monaco, A. P., \& Kunkel, L. M. (1988). The complete sequence of dystrophin predicts a rod-shaped cytoskeletal protein. Cell, 53(2), 219-28.

Laing, N. G. (1993). Molecular genetics and genetic counselling for Duchenne/Becker muscular dystrophy. In: Partridge TA, editor. Molecular and cell biology of muscular dystrophy. (pp. p. 37-84). London: Chapman \& Hall.

Leibowitz, D., \& Dubowitz, V. (1981). Intellect and behaviour in Duchenne muscular dystrophy. Developmental Medicine and Child Neurology, 23(5), 577-90.

Mah, J. K., Tough, S., Fung, T., Douglas-England, K., \& Verhoef, M. (2006). Adolescent quality of life and satisfaction with care. The Journal of Adolescent Health : Official Publication of the Society for Adolescent Medicine, 38(5), 607.e1-7.

Mah, J. K., Thannhauser, J. E., Kolski, H., \& Dewey, D. (2008). Parental stress and quality of life in children with neuromuscular disease. Pediatric Neurology, 39(2), 102-7.

Mah, J. K., Thannhauser, J. E., McNeil, D. A., \& Dewey, D. (2008). Being the lifeline: The parent experience of caring for a child with neuromuscular disease on home mechanical ventilation. Neuromuscular Disorders: NMD, 18(12), 983-8.

Mah, J. K., Selby, K., Campbell, C., Nadeau, A., Tarnopolsky, M., McCormick, A., . . Yoon, G. (2011). A population-based study of dystrophin mutations in Canada. The Canadian Journal of Neurological Sciences. Le Journal Canadien Des Sciences Neurologiques, 38(3), 465-74.

Malik, V., Rodino-Klapac, L. R., Viollet, L., Wall, C., King, W., Al-Dahhak, R., . . Mendell, J. R. (2010). Gentamicin-Induced readthrough of stop codons in Duchenne muscular dystrophy. Annals of Neurology, 67(6), 771-80.

Markham, L. W., Kinnett, K., Wong, B. L., Woodrow Benson, D., \& Cripe, L. H. (2008). Corticosteroid treatment retards development of ventricular dysfunction in Duchenne muscular dystrophy. Neuromuscular Disorders: NMD, 18(5), 365-70.

McMillan, H. J., Campbell, C., Mah, J. K., \& Canadian Paediatric Neuromuscular Group. (2010). Duchenne muscular dystrophy: Canadian paediatric neuromuscular physicians survey. The Canadian Journal of Neurological Sciences. Le Journal Canadien Des Sciences Neurologiques, 37(2), 195-205.

Mendell, J. R., Moxley, R. T., Griggs, R. C., Brooke, M. H., Fenichel, G. M., Miller, J. P., . . . Florence, J. (1989). Randomized, double-blind six-month trial of prednisone in Duchenne's muscular dystrophy. The New England Journal of Medicine, 320(24), 1592-7.

Moore, M. H., Mah, J. K., \& Trute, B. (2009). Family-Centred care and health-related quality of life of patients in paediatric neurosciences. Child: Care, Health and Development, 35(4), 454-61. 
Morine, K. J., Bish, L. T., Selsby, J. T., Gazzara, J. A., Pendrak, K., Sleeper, M. M., . . . Sweeney, H. L. (2010). Activin IIB receptor blockade attenuates dystrophic pathology in a mouse model of Duchenne muscular dystrophy. Muscle $\mathcal{E}$ Nerve, 42(5), 722-30.

Moxley, R. T., Ashwal, S., Pandya, S., Connolly, A., Florence, J., Mathews, K., . . Practice Committee of the Child Neurology Society. (2005). Practice parameter: Corticosteroid treatment of Duchenne dystrophy: Report of the quality standards subcommittee of the American Academy of Neurology and the practice committee of the child neurology society. Neurology, 64(1), 13-20.

Msall, M. E., DiGaudio, K., Rogers, B. T., LaForest, S., Catanzaro, N. L., Campbell, J., . . . Duffy, L. C. (1994). The functional independence measure for children (WeeFIM). Conceptual basis and pilot use in children with developmental disabilities. Clinical Pediatrics, 33(7), 421-30.

Muntoni, F., Bushby, K., \& van Ommen, G. (2005). 128Th ENMC international workshop on 'preclinical optimization and phase I/II clinical trials using antisense oligonucleotides in Duchenne muscular dystrophy' 22-24 October 2004, Naarden, the Netherlands. Neuromuscular Disorders : NMD, 15(6), 450-7.

Muntoni, F., Bushby, K., \& Manzur, A. Y. (2006). Muscular dystrophy campaign funded workshop on management of scoliosis in Duchenne muscular dystrophy 24 January 2005, London, UK. Neuromuscular Disorders: NMD, 16(3), 210-9.

Ottenbacher, K. J., Msall, M. E., Lyon, N. R., Duffy, L. C., Granger, C. V., \& Braun, S. (1997). Interrater agreement and stability of the functional independence measure for children (WeeFIM): Use in children with developmental disabilities. Archives of Physical Medicine and Rehabilitation, 78(12), 1309-15.

Rolland, J. S., \& Walsh, F. (2006). Facilitating family resilience with childhood illness and disability. Current Opinion in Pediatrics, 18(5), 527-38.

Rybakova, I. N., Patel, J. R., \& Ervasti, J. M. (2000). The dystrophin complex forms a mechanically strong link between the sarcolemma and costameric actin. The Journal of Cell Biology, 150(5), 1209-14.

Schara, U., Mortier, \& Mortier, W. (2001). Long-Term steroid therapy in Duchenne muscular dystrophy-positive results versus side effects. Journal of Clinical Neuromuscular Disease, 2(4), 179-83.

Sheras PL, Abidin RR, Konold TR (1998). Stress Index for Parents of Adolescents: Professional manual. Odessa, FL: Psychological Assessment Resources, 7-49.

Schertzer, J. D., van der Poel, C., Shavlakadze, T., Grounds, M. D., \& Lynch, G. S. (2008). Muscle-Specific overexpression of IGF-I improves E-C coupling in skeletal muscle fibers from dystrophic mdx mice. American Journal of Physiology. Cell Physiology, 294(1), C161-8.

Sexton, D., Burrell, B., Thompson, B (1992). Measurement integrity of the Family Needs Survey. Journal of Early Intervention, 16(4), 343-352.

Soo, I., Mah, J. K., Barlow, K., Hamiwka, L., \& Wirrell, E. (2005). Use of complementary and alternative medical therapies in a pediatric neurology clinic. The Canadian Journal of Neurological Sciences. Le Journal Canadien Des Sciences Neurologiques, 32(4), 524-8.

Steele, R. G. (2002). Experiences of families in which a child has a prolonged terminal illness: Modifying factors. International Journal of Palliative Nursing, 8(9), 418-34. 
Takeshima, Y., Yagi, M., Okizuka, Y., Awano, H., Zhang, Z., Yamauchi, Y., . . Matsuo, M. (2010). Mutation spectrum of the dystrophin gene in 442 Duchenne/Becker muscular dystrophy cases from one Japanese referral center. Journal of Human Genetics, 55(6), 379-88.

Tang, Y., Reay, D. P., Salay, M. N., Mi, M. Y., Clemens, P. R., Guttridge, D. C., . . Wang, B. (2010). Inhibition of the IKK/NF-kb pathway by AAV gene transfer improves muscle regeneration in older mdx mice. Gene Therapy, 17(12), 1476-83.

Tinsley, J. M., Fairclough, R. J., Storer, R., Wilkes, F. J., Potter, A. C., Squire, S. E., . . Davies, K. E. (2011). Daily treatment with SMTC1100, a novel small molecule utrophin upregulator, dramatically reduces the dystrophic symptoms in the $\mathrm{mdx}$ mouse. Plos ONE, 6(5), e19189.

Trivette, C. M., Dunst, C. J., Allen, S., \& Wall, L. (1993). Family-Centeredness of the children's health care journal. Children's Health Care: Journal of the Association for the Care of Children's Health, 22(4), 241-56.

Trollet, C., Athanasopoulos, T., Popplewell, L., Malerba, A., \& Dickson, G. (2009). Gene therapy for muscular dystrophy: Current progress and future prospects. Expert Opinion on Biological Therapy, 9(7), 849-66.

van Deutekom, J. C., Janson, A. A., Ginjaar, I. B., Frankhuizen, W. S., Aartsma-Rus, A., Bremmer-Bout, M., . . . van Ommen, G. J. (2007). Local dystrophin restoration with antisense oligonucleotide PRO051. The New England Journal of Medicine, 357(26), 2677-86.

van Kesteren, R. G., Velthuis, B., \& van Leyden, L. W. (2001). Psychosocial problems arising from home ventilation. American Journal of Physical Medicine $\mathcal{E}$ Rehabilitation / Association of Academic Physiatrists, 80(6), 439-46.

Varni, J. W., Seid, M., \& Rode, C. A. (1999). The PedsQL: Measurement model for the pediatric quality of life inventory. Medical Care, 37(2), 126-39.

Varni, J. W., Seid, M., \& Kurtin, P. S. (2001). PedsQL 4.0: Reliability and validity of the pediatric quality of life inventory version 4.0 generic core scales in healthy and patient populations. Medical Care, 39(8), 800-12.

Wagner, K. R. (2008). Approaching a new age in Duchenne muscular dystrophy treatment. Neurotherapeutics : The Journal of the American Society for Experimental Neurotherapeutics, 5(4), 583-91.

Wallace, G. Q., \& McNally, E. M. (2009). Mechanisms of muscle degeneration, regeneration, and repair in the muscular dystrophies. Annual Review of Physiology, 71, 37-57.

Walsh, F. (2003). Family resilience: A framework for clinical practice. Family Process, 42(1), 1-18.

Weidner, N. J. (2005). Developing an interdisciplinary palliative care plan for the patient with muscular dystrophy. Pediatric Annals, 34(7), 546-52.

Welch, E. M., Barton, E. R., Zhuo, J., Tomizawa, Y., Friesen, W. J., Trifillis, P., . . Sweeney, H. L. (2007). PTC124 targets genetic disorders caused by nonsense mutations. Nature, 447(7140), 87-91. 
(C) 2012 The Author(s). Licensee IntechOpen. This is an open access article distributed under the terms of the Creative Commons Attribution 3.0 License, which permits unrestricted use, distribution, and reproduction in any medium, provided the original work is properly cited. 